\title{
Valuation of Non-Performing Loans under Discussion
}

\author{
Emanuel Bagna ${ }^{1}$ \\ ${ }^{1}$ Pavia University, Italy \\ Correspondence: Emanuel Bagna, Pavia University, Italy. E-mail: emanuel.bagna@unipv.it
}

Received: October 1, 2020

doi:10.5539/ijbm.v15n12p25

Accepted: November 3, 2020

Online Published: November 6, 2020

URL: https://doi.org/10.5539/ijbm.v15n12p25

\begin{abstract}
In March 2018, the ECB published "Addendum to the ECB Guidance to banks on non-performing loans: supervisory expectations for prudential provisioning of non-performing exposures" in which it required non-performing loans originated after 1 April 2018 to be fully written down after 7 years, with unsecured loans to be written offer after only 2 years. In practice, this approach implies the use of a null value: $i$ ) after seven years for secured non-performing loans and ii) after two years for unsecured loans, with an accounting provision for an equivalent amount. European Banking Authority (EBA) statistics for 2019 show that provisions for non-performing loans in Europe were $44.9 \%$ (Note 1), corresponding to an NPL valuation of $55.1 \%$, which is higher than the implicit value in the prudential provisions recommended by the ECB. The ECB's new guidelines on provision levels and the implicit value of such provisions creates serious doubt about banks' estimated fair values of NPLs, as per what they book in their accounts. This article aims to use the disclosures provided by listed Italian banks in their notes to the accounts from 2009 to 2019 to determine if the fair value for NPLs, as divided between the secured part and the unsecured part, is value relevant and the amount of any discount/premium applied by the financial market compared to the actual fair value that is booked. The results highlight the excessively prudential nature of completely writing off non-performing loans and justify a review of the approach adopted by the European Council and Parliament in August 2019 (and subsequently adopted by the European Central Bank) in which unsecured NPLs should be fully written off after 3 years (compared to 2 years before), NPLs secured by real estate after 9 years (compared to 7 years before) and NPLs secured by non-real estate guarantees after 7 years (confirming the previous approach) for all loans originated after 26 April 2019.
\end{abstract}

Keywords: valuation, non performing loans, bank

\section{Introduction}

In March 2017, the European Central Bank published "Guidance to banks on non performing loans" setting out its supervisory expectations for managing the entire life cycle of non-performing loans, from the time they are classified as such and booked in the accounts, to the strategy for managing them (sold on the market, or managed internally). The document has an entire section on dealing with the valuation of non-performing loans on the basis of the principle that it is impossible to manage what cannot be valued. The valuation differences for different loans can be ascribed to four different factors:

a) The nature of the guarantee securing the loan (pledge, mortgage, other collateral or personal guarantee).

b) The NPL vintage, that is, the date on which the loan was classified as non-performing.

c) The credit recovery method - via the liquidation of the company or the entire group, or a workout plan. In the first scenario - often called the "gone concern" - the loan is recovered through the liquidation of the company, which involves:

o where a guarantee is present, the enforcement of the guarantees, which have been valued using predefined haircuts and, at times, using new expert appraisals;

o where no guarantees are present, the recoverability assessment is performed using the value of the assets based on the forecast once the secured loans have been repaid.

In the second scenario, since the debtor is believed to be able to repay the loan through its own activities, the estimated recoverable value is calculated on the basis of the company's value (as estimated using an approach based on forecast future cash flows usually based on the workout agreement) and the seniority of the debts. 
d) The sector.

The European Central Bank previously identified these factors as the drivers for valuing an NPL and the consequent workout strategy when defining the rules for the "Asset Quality Review" (Asset Quality Review Phase 2 Manual, June 2018).

In terms of the different valuations for the sector concerned, in the June 2018 Asset Quality Review manual, the ECB indicated that a credit review can be performed using multiples (typically equal to 12 times cash flow for companies in infrastructure, 10 times for utilities and 6 times for other sectors, excluding financial ones) and that multiples are similar within an industry and geographic area (and validating them is part of the quality control process).

For the nature of the guarantee and loan vintage, in October 2017, the European Central Bank published an addendum to it guidance for banks on non-performing loans in which it details the minimum prudential provision levels for NPLs. The document was part of the consultation process and it indicated a prudential provision of $100 \%$ of the value of the NPE by:

- 7 years for secured NPEs (with an annual linear provision of ca. 15\%)

- 2 years for unsecured NPEs (with an annual linear provision of 50\% of the amount initially booked in the accounts). The document expressly indicated that, should an accounting provision be impossible, then a deduction from regulatory capital was required.

In March 2018, the ECB issued the final document ("Addendum to the ECB Guidance to banks on non-performing loans: supervisory expectations for prudential provisioning of non-performing exposures") in which:

a) It confirmed its expectation that secured NPEs be written off within 7 years, and unsecured NPEs within 2 years, as per table 1 .

b) It specified the rules for these write-downs were for new NPEs (and not existing stock) originated after 1 April 2018.

c) It indicated it would interact with each bank to define the individual supervisory expectations based on a benchmarking comparison of similar banks and taking into account the current level of the NPL ratio and other financial indicators for each bank as part of the Supervisory Review and Evaluation Process (SREP).

Table 1.Model for writing off secured and unsecured NPEs

\begin{tabular}{|c|c|c|}
\hline & Unsecured part & Secured part \\
\hline After two years of NPE vintage & $100 \%$ & \\
\hline After three years of NPE vintage & & $40 \%$ \\
\hline After four years of NPE vintage & & $55 \%$ \\
\hline After five years of NPE vintage & & $70 \%$ \\
\hline After six years of NPE vintage & & $85 \%$ \\
\hline After seven years of NPE vintage & & $100 \%$ \\
\hline
\end{tabular}

Source: ECB Document "Addendum to the ECB Guidance to banks on non-performing loans," Table 1 p. 11.

Requiring the complete write off of NPEs within 2 or 7 years, depending on the guarantee, had the undoubted advantage of encouraging banks to deal with NPEs swiftly, initially by seeking an internal workout solution and then moving onto selling the loan to a third party via the market, as the danger was banks would end up booking hefty provisions and requiring a consequent capital increase to keep capital levels within the required Common Equity Tier 1 Ratio.

Yet, this same excess of prudence in determining provisions would become a disadvantage to the degree that such provisions would decrease the banks own regulatory capital, forcing the shareholders to restore this value (ultimately through a capital increase). In the wake of the Lehman Brothers default, it was found (Di Martino \& 
Bussato, 2018 Note 2) that the price of banks that sought capital increases dropped significantly, indicating an over-reaction at the time of the announcement compared to the price dynamics in that context for companies in other sectors.

The case of the Italian bank Banca Monte dei Paschi di Siena provides a telling example of the effect of announcing write-downs for NPLs and the consequent supervisory actions. On Friday 11 January 2019, after the market had closed, a press release was issued detailing the results of the SREP (Supervisory Review and Evaluation Process) with the European Central Bank. Specifically in terms of non-performing loan coverage, Banca Monte dei Paschi di Siena indicated the European Central Bank was requesting the complete write off of NPEs by 2026, both for NPEs originated before 1 April 2018 and new NPEs:

"In this context, BMPS is recommended to implement, over the next few years (up to the end of 2026) a gradual increase in coverage levels on the stock of non-performing loans outstanding at the end of March 2018, according to a complementary approach with the indications set, in the Addendum to the ECB Guidance to Banks on non-performing loans, for NPL flows generated starting from April 2018." (Source: Banca Monte dei Paschi di Siena press release on 11 January 2019).

The market reacted negatively, but not only for Monte dei Paschi di Siena, as other Italian banks also felt the effects. In the two days after the announcement, Credito Valtellinese lost $9.78 \%$, compared to a general drop in the stock market of $-1.01 \%$ (table 2). The reaction of the banking market highlights the importance of the variable for loan write-downs in explaining stock market prices.

Table 2. Reaction for the prices of listed Italian banks following the BMPS announcement that it had to write off its NPEs from before 01/04/2018

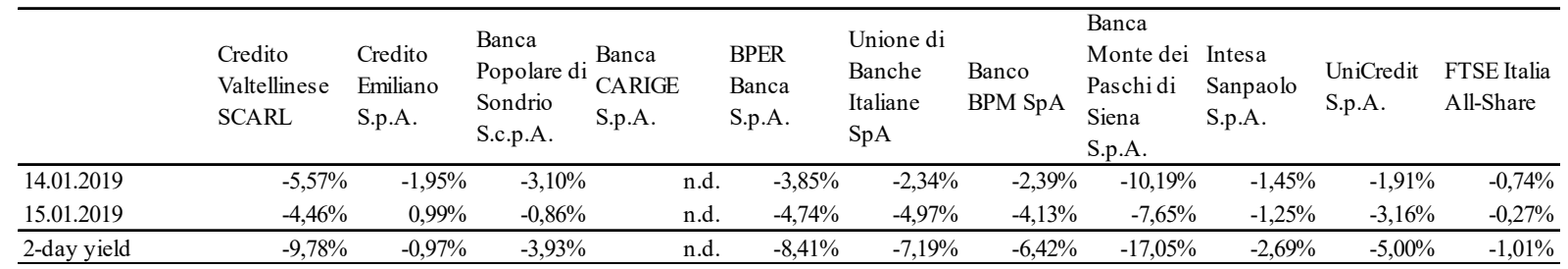

Source: FactSet.

The ECB's approach has been criticised from numerous sides. On 25 April 2019, Regulation (EU) 2019/630 of the European Parliament and of the Council of 17 April 2019 as regards minimum loss coverage for non-performing exposures was published in the Official Journal of the European Union. The provision levels were adopted by the European Central Bank on 22 August 2019 in its "Communication on supervisory coverage expectations for NPEs."

The new Regulation - applicable to new loans originated after 26 April 2019 and subsequently classified as non-performing - introduced minimum coverage percentages for NPEs to be applied by certain deadlines set according to the date when the exposure was classified as non performing. The required coverage levels differ for secured and unsecured loans:

- Should an exposure not be backed by any form of guarantee, the write-down must be $100 \%$ within 3 years of being classified as non performing (compared to 2 years previously).

- Should an exposure be secured, then the provisions are more gradual, starting from 3 years to reach $100 \%$ by 7 years for real estate collateral (thus confirming the previous approach) and by 9 years for other guarantees (table 3).

- Should the coverage not meet the regulatory requirements, measures that have an impact on the bank's capital would need to be considered.

\section{Literature Review}

The Addendum to the European Central Bank guidance approved in March 2018 implicitly imposed, through the prudential provisions, a valuation of unsecured non-performing exposures equal to:

a) $50 \%$ of the gross value of the loan one year from the date on which the exposure was classified as non performing.

b) 0 a further year after the date on which the exposure was classified as non performing. 
For secured exposures, the fair value implicit in the new provision levels is equal to:

a) $40 \%$ of the gross value of the loan three years from the date on which the exposure was classified as non performing.

b) 0 seven years after the date on which the exposure was classified as non performing.

In November 2019, the EBA highlighted that, on 30 June 2019, 17\% of non-performing loans held by European banks had a vintage of over 5 years, while for $29 \%$ the vintage was 1 to 5 years, with the vintage for the remaining $54 \%$ of non-performing loans at less than 1 year (of which, $40 \%$ were in the unlikely-to-pay category). Imagining a portfolio split into $35 \%$ unsecured loans and $65 \%$ secured loans (Note 3 ), the value of the loan portfolio would be $40.34 \%$ of the total loan value, which is significantly below the average valuation coefficient for European banks of $55.1 \%$. (Note 4). The loan valuation coefficients implicit in the provision levels required by the ECB Addendum have seriously questioned the methods used by banks for estimating the fair value of non-performing exposures (Note 5) and their value relevance.

Table 3. Provisioning time frames for loans originated after 26 April 2019 as set out by Regulation (EU) 2019/630 amending the CRR (Regulation (EU) No. 575/2013)

\begin{tabular}{|c|c|c|c|c|c|c|c|c|c|c|}
\hline & $\begin{array}{l}\text { Anerer year } \\
\text { of vintage }\end{array}$ & 1 & 2 & 3 & 4 & 5 & 6 & 7 & 8 & 9 \\
\hline \multirow{3}{*}{ CRR } & $\begin{array}{l}\text { Seared by } \\
\text { immovable } \\
\text { collateral }\end{array}$ & - & - & $29 \%$ & $35 \%$ & $99 \%$ & $70 \%$ & 806 & $89 \%$ & $100 \%$ \\
\hline & $\begin{array}{l}\text { Seaured by } \\
\text { movase } \\
\text { collateral }\end{array}$ & - & - & $29 \%$ & $35 \%$ & $95 \%$ & $80 \%$ & $100 \%$ & & \\
\hline & Unsecured & - & $39 \%$ & $100 \%$ & & & & & & \\
\hline
\end{tabular}

Source: EBA Report on NPLs - progress made and challenges ahead, p. 32.

One potential explanation for the difference between the implicit value in the financial statements of banks and those implicit in the new approach adopted by the European Central Bank could be the different configurations of value. The fair value estimate implicit in the financial statements of banks would match value in use, while the implicit values in the ECB's proposed coefficients would match fair value less cost to sell.

In its December 2019 publication "I tassi di recupero delle sofferenze nel 2018" (literally, Recovery rates for NPEs in 2018), the Bank of Italy highlights how the recovery rates implicit in comparable transactions and those implicit in the same banks recovery of credit (which is in practice the amount booked in the accounts by banks, as based on historical recovery rates for non-performing and unlikely-to-pay loans) are notably different due to the significant gap between fair value and value in use for an NPE. The study focuses on the entire Italian banking system. Overall, the differential found for secured NPEs in 2018 (most recent year available) was 17.3\%, while the same differential but for unsecured exposures was $16.9 \%$.

The data calculations by the Bank of Italy are based on figures from the Italian Central Credit Register (Centrale dei Rischi) and show the actual recovery rates for NPEs for the entire Italian banking system in the last 12 years (from 2006 to 2018, inclusive), dividing the recovery rates between the rates for directly recovering the exposure and those achieved through a transfer to a third party.

Table 4 restates Table A2 and Figure 1 from the publication (Table A2 - Recovery rates: presence of real estate guarantees and type of closure; Figure 1 - Recovery rate and equivalent value for the NPEs by year and type of closure) and shows how, for 2018, the recovery rate through transfers to third parties stood at $30.4 \%$, while the recovery rate without a third party transfer (credit recovered by the bank afterwards) was $45.9 \%$. It should be noted these figures only relate to NPEs, which have lower recovery rates than unlikely-to-pay exposures.

The European Central Bank's view matches that of Beaver et al. (1989), who developed a valuation criterion for banks designed to explain the differential between market capitalisation of their shares and equity net of the bank's goodwill and intangibles. This specifically relates to the intangible linked to deposits (core deposit intangible) that is not captured by the historical cost accounting method for bank deposits and by the goodwill/badwill from maturity transformations and the management of non-performing loans. By regressing the differential between stock market prices and equity net of intangibles for a group of banks in relation to a set of variables that capture the value of core deposits, of non-performing loans and of the value generated by maturity transformations, the author identifies statistically significant parameters that are consistent with the assumptions 
made. The author identifies a negative coefficient for the amount of non-performing loans, indicating the market valuation of non-performing loans is clearly lower than the book value (a negative value is implicitly identified).

Table 4. Recovery rates for loans estimated by the Bank of Italy for the Italian banking system

\begin{tabular}{|c|c|c|c|c|c|c|c|c|c|}
\hline & Position not & transferred $t$ & d parties & Position & $\begin{array}{l}\text { transferred } t \\
\text { parties }\end{array}$ & third & \multicolumn{3}{|c|}{$\begin{array}{l}\text { Value change (Position not transferred } \\
\text { Position transferred) }\end{array}$} \\
\hline Year & $\begin{array}{l}\text { No real } \\
\text { estate } \\
\text { guarantees }\end{array}$ & $\begin{array}{l}\text { Real estate } \\
\text { guarantees }\end{array}$ & Total & $\begin{array}{l}\text { No real } \\
\text { estate } \\
\text { guarantees }\end{array}$ & $\begin{array}{l}\text { Real estate } \\
\text { guarantees }\end{array}$ & Total & $\begin{array}{l}\text { No real } \\
\text { estate } \\
\text { guarantees }\end{array}$ & $\begin{array}{l}\text { Real estate } \\
\text { guarantees }\end{array}$ & Total \\
\hline 2006 & 41.6 & 61.9 & 48.4 & 24.0 & 47.0 & 30.2 & 17.6 & 14.9 & 18.2 \\
\hline 2007 & 44.4 & 60.9 & 50.1 & 20.1 & 45.3 & 22.1 & 24.3 & 15.6 & 28.1 \\
\hline 2008 & 36.7 & 56.4 & 44.8 & 22.7 & 47.4 & 37.4 & 14.0 & 9.0 & 7.3 \\
\hline 2009 & 41.1 & 60.9 & 50.0 & 25.5 & 41.8 & 28.9 & 15.6 & 19.1 & 21.1 \\
\hline 2010 & 43.0 & 59.4 & 49.3 & 23.4 & 32.2 & 26.7 & 19.6 & 27.2 & 22.6 \\
\hline 2011 & 39.0 & 55.7 & 46.1 & 17.6 & 33.9 & 23.3 & 21.4 & 21.8 & 22.8 \\
\hline 2012 & 46.7 & 61.5 & 53.0 & 16.6 & 51.9 & 29.8 & 30.1 & 9.6 & 23.1 \\
\hline 2013 & 39.0 & 58.8 & 46.9 & 14.2 & 39.0 & 23.8 & 24.8 & 19.8 & 23.1 \\
\hline 2014 & 30.4 & 52.0 & 39.0 & 16.5 & 31.1 & 22.4 & 13.9 & 20.9 & 16.6 \\
\hline 2015 & 39.5 & 52.0 & 44.9 & 15.3 & 30.5 & 20.3 & 24.2 & 21.5 & 24.7 \\
\hline 2016 & 32.2 & 53.6 & 43.5 & 15.2 & 36.6 & 23.5 & 17.0 & 17.0 & 20.0 \\
\hline 2017 & 31.0 & 54.6 & 44.3 & 18.1 & 33.3 & 26.1 & 12.9 & 21.3 & 18.2 \\
\hline 2018 & 36.1 & 52.4 & 45.9 & 18.8 & 35.5 & 30.4 & 17.3 & 16.9 & 15.5 \\
\hline Total & 38.5 & 56.9 & 46.2 & 19.1 & 38.9 & 28.0 & 19.4 & 18.0 & 18.2 \\
\hline
\end{tabular}

Source: Calculations using Bank of Italy Publication (2019) "I tassi di recupero delle sofferenze nel 2018"

Table 2 Recovery rates: real estate guarantees and type of closure and Figure 1 - Recovery rate and value of the NPEs by year and type of closure of the position.

On the other hand, the author found a clearly positive coefficient for NPL provisions, partially offsetting the reduction in non-performing asset value indicated in the previous point, although not sufficiently to fully offset the differential between the implicit value in the financial statements and the implicit value in the beta coefficient estimated on non-performing loans. Nissim (2003) showed the reliability of the fair value estimates by banks was limited by earnings management policies that led certain banks, in the United States, to overestimate fair value in order to positively influence investor assessments of risk and capital levels.

In 2003, Kim and Khurana analysed the value relevance of fair value and book value of loans to customers, and stated that the historical cost of loans for smaller banks had more explanatory power than the market value. Subsequently, in 2011, a study by Chee that examined the cash flow estimates of loans showed the fair value estimate of loans was more value relevant and expressive in a forward looking perspective as it was able, at the time of measurement, to capture all the information and forecasts for credit risk.

In summary, the literature on fair value of NPLs is uncertain about the reliability of the figures in the financial statements. One possible explanation can be found in the Bank of Italy's finding that, for Italian banks, for exposures that are transferred to third parties, the fair value was significantly lower than the value implicit in recovery rates for positions not transferred to third parties.

\section{Assessment of the Value on NPLS in Italy}

The disclosures by European banks are fragmented and lack uniformity, making it generally impossible to retrieve detailed information about non-performing loans, their vintage and to what degree they are secured or unsecured. The Italian banks are an exception on this front because of the information the Bank of Italy recommends be included in the notes to the accounts, making it possible to obtain information:

a) To group performing (and non-performing) loans into three sub-categories, namely secured loans, partially secured loans and unsecured loans.

b) To determine the breakdown between real estate guarantees and other types of guarantees.

Importantly, the accounting information for such breakdowns is uniform for the different banks. However, it is not possible to determine the vintage of non-performing loans.

In order to determine the value relevance of non-performing loans in relation to whether and to what degree they are secured (real estate guarantee versus other types of guarantees) information was obtained from the notes to the financial statements of listed Italian banks (Banca Carige, Banca Popolare dell'Etruria e del Lazio, Banca Monte dei Paschi di Siena, Banca Popolare di Sondrio, Banca Popolare di Emilia Romagna, Banco di Desio e 
della Brianza, Banca Popolare di Milano and Banco Popolare - merged in Banco BPM, Mediobanca, Credito Emiliano, Intesa Sanpaolo, UniCredit) to determine the value of non-performing loans (Stage III, IFRS) and performing loans (Stages I and II), dividing these into secured and unsecured, following the Lehman Brothers collapse (31/12/2009 to 31/12/2019). The Price to Tangible Book Value (P/TBV) multiples for listed Italian banks were then regressed on the following drivers:

a) Current profitability level, as taken from the respective financial statements. The profitability used was calculated as the profit from the year compared to equity net of intangible assets on the same date. Net profit is net of any goodwill write-downs. The source for the figures is FacSet Fundamentals.

b) Since there is a behavioural difference between banks with positive profitability and those with negative profitability, a dummy variable was introduced - Return on Tangible Equity dummy (ROTE dummy) and had a value of one if ROTE was negative, otherwise it was 0 . This variable was introduced to neutralise the distorting effect that negative ROTE would have had on the P/TBV multiple. Negative ROTE would imply negative P/TBV. However, this would have been inconsistent because in banking $\mathrm{P} / \mathrm{TBV}$ is always positive as both price and tangible book value are positive by definition. In fundamental terms, this dummy variable makes it possible, when forecast growth is the same, to recover the profitability the market discounts on the price. The P/TBV multiple is positive despite negative profitability. The $\beta$ D-ROTE coefficient should be close to $\beta$ ROTE in absolute value, while the sign should be negative, that is, for a bank that has negative ROTE, the ROTE dummy neutralises this effect on the multiple.

c) The total of performing loans (in what IFRS calls "stages one and two") based on the most recent financial statements (net of any write-downs) grouped into secured, partially secured and unsecured. Based on the most recently available statements, the figure is taken from subsection A.3.2 in the accounts ("A.3.2. Prudential Consolidation - Guaranteed on- and off-balance sheet credit exposures to customers").

d) The total for net impaired loans based on the latest financial statements (non-performing, unlikely-to-pay, past due - as per IFRS's "stage three"), divided into secured, partially secured and unsecured. The secured loans were then further broken down into those with real estate guarantees and other forms of guarantees.

e) An indicator of the degree of financial leverage, as per the ratio between tangible book value and total assets for the year in question.

f) An indicator of the analysis year, captured using a specific dummy variable - years - that had a value of one if the observations referred specifically to the year of analysis, otherwise it was zero.

The difference between one financial year and the next is not only captured by the dummy variables, but also by the different levels of profitability and by the different amounts of impaired loans (reduced progressively over time).

In place of prices and specific market capitalisation on the analysis date (31/12 of each year), the 3-month average daily capitalisation was used, as at 31 March of each year. All the data, except for those obtained manually, are from FactSet Fundamentals.

The regression is as follows:

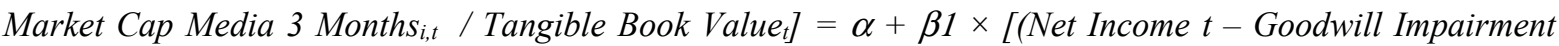
Losses Net of Taxes t) / Tangible Equity Last Reported] $+\beta 2 \times($ Tangible Equity Last Reported / Total Asset] + $\beta 3 \times($ Net secured performing loans $t /$ Tangible Equity $t)+\beta 4 \times($ Net partially secured performing loans $t /$ Tangible Equity $t)+\beta 5 \times($ Net unsecured performing loans $t /$ Tangible Equity $t)+\beta 6 \times($ Total non-performing loans secured with real estate $t /$ Tangible Equity $t)+\beta 7 \times($ Partially secured non-performing loans $t /$ Tangible Equity $t)+\beta 8 \times($ Unsecured non-performing loans $t /$ Tangible Equity $t)+\beta 9 x$ (Non-performing loans fully secured with non-real estate guarantees $t /$ Tangible Equity $t)+\sum \beta j=10-20 x$ Dummy Year $j$

The regression makes it possible to determine the discount, applied by the market, as a reduction in Price to Tangible Book Value in relation to total loans divided into the various categories, once the control variables have been considered:

a) Profitability

b) Leverage (not already captured by the ratio between the various loan categories and tangible book value) 
c) Observation year.

The coefficients $\beta 3$ (...) $\beta 9$ express any discount applied by the market compared to the book value (which is a measure of fair value for non-performing loans, while for performing loans it measures the amortised cost).

Table 5 shows the descriptive statistics, while table 6 has the correlation matrix. Table 5 presents a Price to Tangible Book Value multiple equal to, on average, 0.604, with significant dispersion (standard deviation $=$ 0.294). The non-performing loans secured by immovable property account for, on average, $100.4 \%$ of tangible book value, while those secured with other forms of guarantees, $49.4 \%$. These values are significantly lower than non-performing loans without any guarantees, at $20.9 \%$ of tangible book value on average.

Table 5. Descriptive statistics

\begin{tabular}{|c|c|c|c|c|c|c|c|c|}
\hline & Valid N & Mean & Median & Min. & Max & $\begin{array}{c}\text { I } \\
\text { Quartile }\end{array}$ & $\begin{array}{c}\text { III } \\
\text { Quartile }\end{array}$ & Std.Dev. \\
\hline Price to Tangible Book Value & 140 & 0,604 & 0,547 & 0,050 & 1,469 & 0,372 & 0,783 & 0,294 \\
\hline Leverage $=$ Tangible Book Value $/$ Tangible Asset & 142 & 0,062 & 0,059 & 0,024 & 0,124 & 0,050 & 0,069 & 0,018 \\
\hline Rote $=$ Return on Tangible Equity & 142 & $-0,056$ & 0,037 & $-1,585$ & 0,151 & $-0,038$ & 0,064 & 0,240 \\
\hline Dummy Negative Rote x Rote & 142 & $-0,092$ & 0,000 & $-1,585$ & 0,000 & $-0,038$ & 0,000 & 0,223 \\
\hline $\begin{array}{l}\text { Non Performing Loans - Fully Guaranteed - Other } \\
\text { than Real Estate }\end{array}$ & 138 & 0,494 & 0,167 & 0,002 & 5,008 & 0,079 & 0,346 & 0,882 \\
\hline $\begin{array}{l}\text { Non Performing Loans - Fully Guaranteed - Real } \\
\text { Estate }\end{array}$ & 142 & 1,040 & 0,650 & 0,000 & 6,501 & 0,295 & 1,402 & 1,200 \\
\hline Non Performing Loans - Partially Guaranteed & 138 & 0,083 & 0,054 & 0,001 & 0,328 & 0,029 & 0,136 & 0,073 \\
\hline Non Performing Loans - Without Guarantees & 137 & 0,209 & 0,175 & $-0,133$ & 1,228 & 0,080 & 0,284 & 0,192 \\
\hline Performing Loans Fully Guaranteed & 138 & 5,599 & 5,468 & $-0,906$ & 13,780 & 4,232 & 6,802 & 2,401 \\
\hline Performing Loans - Partially Guaranteed & 138 & 0,701 & 0,440 & 0,106 & 4,006 & 0,297 & 0,729 & 0,688 \\
\hline Performing Loans - Without Guarantees & 137 & 3,583 & 3,305 & 1,332 & 9,924 & 2,665 & 4,215 & 1,408 \\
\hline
\end{tabular}

Table 6 represents how the Price to Tangible Book Value multiple is not only explained by Return on Tangible Equity (correlation coefficient $=0.277$ ) but also linked to:

a) The non-performing loans secured by real estate and other guarantees, with a negative correlation to the multiple: at increased levels of non-performing loans, lesser multiples are found.

b) The unsecured performing loans, with a positive correlation to the multiple: at increased levels of unsecured performing loans, greater multiples are found.

The non-performing loans are found to be negatively correlated to the profitability level.

Table 6. Correlation matrix

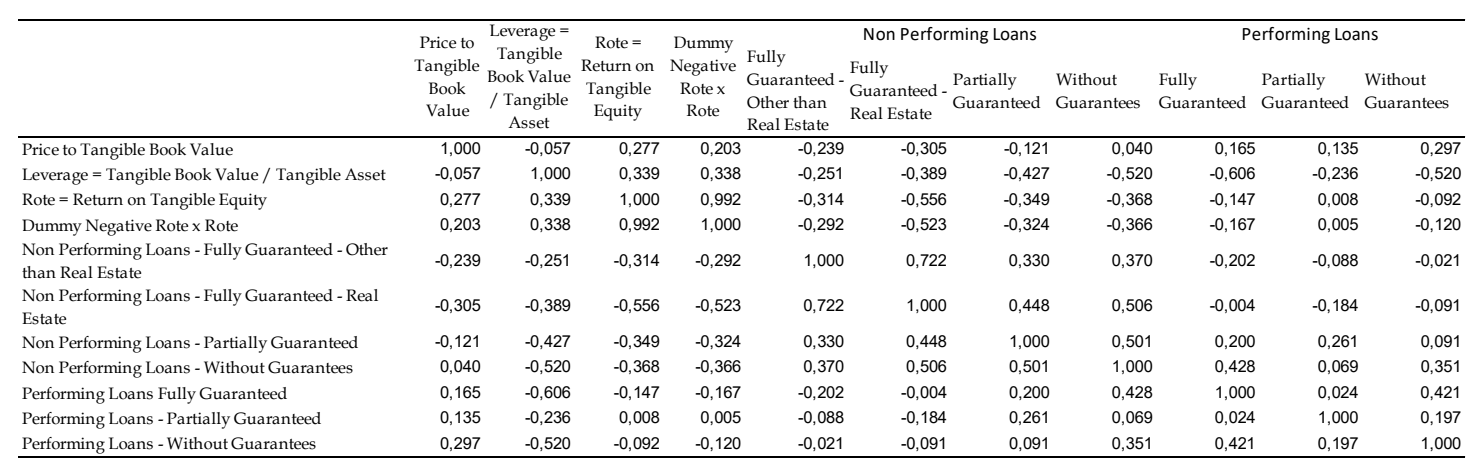

The regression shows (table 7) significant discounts for non-performing loans, especially:

- The non-performing loans with real estate guarantees are discounted by $4.24 \%$ compared to the book value.

- The non-performing loans with other forms of guarantees are discounted by $4.38 \%$ compared to the book value, in practice aligned with the discount for loans secured by real estate; in practice, the market 
does not differentiate between non-performing loans secured by real estate collateral and those secured by other forms of guarantee.

- The unsecured non-performing loans have the largest discount, at $29.506 \%$ compared to the book balue.

Table 7. Regression Results

Market Cap Media 3 Monthsi,t / Tangible Book Valuet $]=\alpha+\beta 1 \times$ [(Net Income $t-$ Goodwill Impairment Losses Net of Taxes t) / Tangible Equity Last Reported] $+\beta 2 \times$ (Tangible Equity Last Reported / Total Asset] $+\beta 3 \times$ (Net secured performing loans $t /$ Tangible Equity $t)+\beta 4 \times($ Net partially secured performing loans $t /$ Tangible Equity $t)+\beta 5 \times($ Net unsecured performing loans $t /$ Tangible Equity $t)+\beta 6 \times($ Total non-performing loans secured with real estate $t /$ Tangible Equity $t)+\beta 7 \times($ Partially secured non-performing loans $t /$ Tangible Equity $t)+\beta 8 \times($ Unsecured non-performing loans $t /$ Tangible Equity $t)+\beta 9 x$ (Non-performing loans fully secured with non-real estate guarantees $t /$ Tangible Equity $t)+$ $\sum \beta j=10-20 \times$ Dummy Year $j$

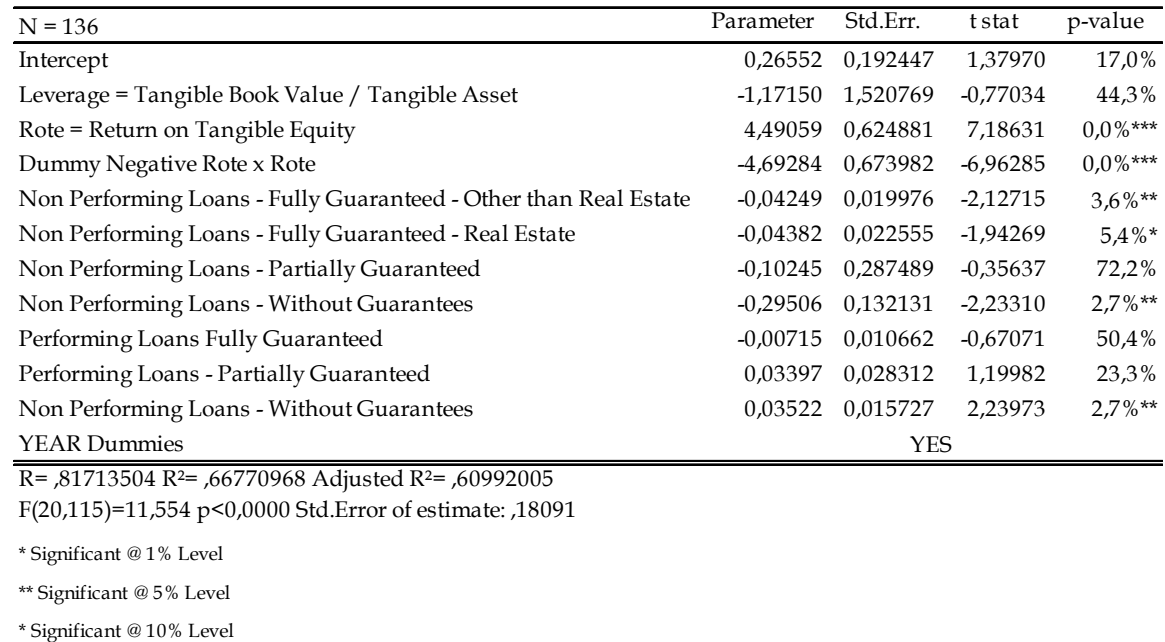

The variable linked to profitability is significant, just like the ROTE dummy variable. The value for the variable linked to capitalisation is not statistically significant. The coefficient linked to partially secured non-performing loans is not significant both because this loan category is a residual group and because it is so indefinitely defined.

The financial market does not discount a secured performing loan portfolio. By contrast, the market seems to apply a premium to the unsecured performing portfolio. It should be noted performing loans are booked at historical cost, while non-performing loans are shown at fair value. Thus, the premium applied for performing loans could be tied to the financial markets estimating fair value above the historical cost.

\section{Conclusions}

In March 2018, the ECB published "Addendum to the ECB Guidance to banks on non-performing loans: supervisory expectations for prudential provisioning of non-performing exposures" in which it required loans originated after 1 April 2018 to be fully written down after 7 years, with unsecured loans to be written off after only 2 years. The approach implies assigning a fair value for non-performing loans of zero after seven years in the secured non-performing loans category and after two years in the unsecured non-performing loans category.

The new approach has several implication for the management of a bank, ranging from the management of NPLs, to the calibration of the timing for the possible transfer of NPLs outside, to the choices in terms of capitalization of the bank consequent to the implicit write-downs in the new approach.

The implicit valuations in this approach question the book values in bank accounts, which already express fair value for non-performing loans.

This study, using the information disclosed by Italian banks in the notes to the balance sheet for the fair value of secured and unsecured non-performing loans (handly collected), showed that the implicit value in stock market prices for secured non-performing loans is roughly $4 \%$ below the published book value. This amount is lower 
than the book value, but not large enough to justify the implicit valuation in the ECB approach. By contrast, unsecured NPLs are discounted by $30 \%$ on average compared to their book values. The discount applied by the financial market for this category of NPLs would seem to be more in line with the differential of $19.4 \%$ found by the Bank of Italy for the period 2006 - 2018 for Italian banks between the value of unsecured non-performing loans transferred to third parties and those recovered internally by banks. Different configurations of value would justify this difference, with one reflecting value in use according to international accounting standards and the other, fair value. The limit of this study is represented by the fact that the sample consists only of Italian listed banks and implicitly extends the results of the analysis carried out to European banks.

The results of the analysis show the approach in which non-performing loans are completely written off is excessively prudential, This conclusion is consistent with the revision of the approach adopted by the European Council and Parliament in August 2019 (and implemented subsequently by the European Central Bank) that sets out the complete write off of unsecured non-performing loans after 3 years (compared to 2 years previously), non-performing loans secured by real estate after 9 years (compared to 7 years previously) and non-performing loans with non-real estate guarantees after 7 years (confirming the previous approach) for all loans originated after 26 April 2019. Nonetheless, it still does not justify the different treatment for NPLs secured by real estate guarantees and those by other forms of guarantees.

\section{References}

Bagna E. (2018). Is There Any Value in the Banks Brand? International Journal of Business and Management, 13(12).

Bagna E., \& Cotta, R. E. (2017). Market Multiples and the Valuation Cyclical Companies. International Business Research, 10(12).

Bagna, E., Dicuonzo, G., Perrone, A., \& Dell'Atti, V. (2017). The value relevance of brand valuation. Applied Economics, 49(58). https://doi.org/10.1080/00036846.2017.1352078

Bagna, E., Di Martino, G., \& Rossi, D. (2015). No more discount under enhanced fair value hierarchy. Applied Economics, 47(51). https://doi.org/10.1080/00036846.2015.1054068

Bagna, E., \& Ramusino, E. C. (2017). Market Multiples and the Valuation of Cyclical Companies. International Business Research, 10(12). https://doi.org/10.5539/ibr.v10n12p246

Bagna, E., Bini, M., Bird, R., Momentè, F., \& Reggiani, F. (2010). Accounting for employee stock options: What can we learn from the market's perceptions? Journal of International Financial Management \& Accounting, 21(2). 161-186. https://onlinelibrary.wiley.com/doi/full/10.1111/j.1467-646X.2010.01039.x

Bagna, E. (2012). La Valutazione delle Banche EGEA. ISBN 9788823843332

Bagna, E., \& Di Martino, G. (2013). La value relevance della fair value hierarchy nel settore bancario europeo. Finanza Marketing E Produzione. 4.

Bank of Italy. (2019). I tassi di recupero delle sofferenze nel 2018

Beaver, W., Eger, C., \& Ryan, W. M. (1989). Financial Reporting. supplemental disclosure and bank share prices. Journal of Accounting Research, 27, 157-178.

Beaver, W., \& Venkatachalam, M. (2003). Differential Pricing of Components of Bank Loan Fair Values. Journal of Accounting. Auditing and Financ, 18, 41-67.

Beck, R., \& Jakubik, P. (2015). Key determinants of Non performing loans: New Evidence from a Global Sample. Open Economies Review, 26(3).

Beck, R., \& Jakubik, P. (2013). Non performing loans. What matters in addition to the economic cycle? Working Paper Series 1515, European Central Bank.

Calomiris, C., \& Nissim, D. (2007). Activity-Based Valuation of Bank Holding Companies. NBER Working Paper No. W12918.

Chee S. (2011). The Information Content of Commercial Banks' Fair Value Disclosure of Loans under SFAS No. 107. Working Paper. University of California

Khurama, I. K., \& Kim, M. (2003). Relative Value Relevance of Historical Cost vs. Fair Value: Evidence from Banking Holding Companies. Journal of Accounting and Public Policy, 22, 19-42.

European Banking Authority -EBA. (2019). Report on NPLs - progress made and challenges ahead.

European Central Bank. (2018). Addendum to the ECB Guidance to banks on non-performing loans: supervisory 
expectations for prudential provisioning of non-performing exposures.

European Central Bank. (2017). Guidance to banks on non -performing loans.

European Central Bank. (2019). Communication on supervisory coverage expectations for NPEs.

Nissim, D. (2003) Reliability of banks' fair value disclosure for loans. Review of Quantitative Finance and Accounting, 20

Notes

Note 1. EBA REPORT ON NPLs PROGRESS MADE AND CHALLENGES AHEAD - 08/11/2019 downloadable

https://eba.europa.eu/eba-shows-efforts-improve-eu-banks $\% \mathrm{E} 2 \% 80 \% 99$-asset-quality-have-proven-successful-p ockets-risks-remain

Note 2. Equity Rights Issue and Dilutive Effect: Evidence from Italian Listed Companies. International Business Research; Vol. 11, No. 10; 2018, ISSN 1913-9004 E-ISSN 1913-9012.

Note 3. The EBA found that, on average, $36 \%$ of the loan portfolio of European banks is secured, with the remainder unsecured.

Note 4. On the basis of the following assumptions:

\begin{tabular}{|c|c|c|c|c|}
\hline $\begin{array}{l}\text { A) Past Due } \\
\text { Category }\end{array}$ & $\begin{array}{l}\text { B) NPL \% by Past } \\
\text { Due Category }\end{array}$ & $\begin{array}{l}\text { C) Secured NPL } \\
\text { Value (Fair Value / } \\
\text { t Gross Loan Value) } \\
\text { y as Stated by ECB }\end{array}$ & $\begin{array}{l}\text { D) Unsecured } \\
\text { NPL Value (Fair } \\
\text { Value / Gross } \\
\text { Loan Value) as } \\
\text { Stated by ECB }\end{array}$ & $\begin{array}{l}\text { E) Portfolio Unsecured } \\
\text { and Secured NPL Value } \\
\text { (Fair Value / Gross Loan } \\
\text { Value) as Stated by ECB = } \\
35 \% \times C+65 \% \times D\end{array}$ \\
\hline$>5$ Years & $17,0 \%$ & $67,50 \%$ & $0,0 \%$ & $2,63 \%$ \\
\hline$>1$ Year $<5$ Years & $29,0 \%$ & $52,5 \%$ & $0,0 \%$ & $18,38 \%$ \\
\hline$<1$ Year & $54,0 \%$ & $90,0 \%$ & $50,0 \%$ & $64,00 \%$ \\
\hline Total & $100,0 \%$ & $65,1 \%$ & $27,0 \%$ & $40,34 \%$ \\
\hline
\end{tabular}

Note 5. On this front, it should be remembered that, under International Accounting Standards, the valuation of performing loans in the financial statements follows the logic of amortised cost, while for impaired loans the logic of full fair value accounting is used.

\section{Copyrights}

Copyright for this article is retained by the author(s), with first publication rights granted to the journal.

This is an open-access article distributed under the terms and conditions of the Creative Commons Attribution license (http://creativecommons.org/licenses/by/4.0/). 